\title{
Anatomic Position of the Asterion and Implication for Neurosurgical Procedure
}

\author{
Posición Anatómica del Asterion y sus Implicancias en el Procedimiento Neuroquirúrgico
}

Wimon Wirakiat $^{1}$; Anukoon Kaewborisutsakul ${ }^{2}$ \& Wilairat Kankuan Kaewborisutsakul ${ }^{1}$

WIRAKIAT, W.; KAEWBORISUTSAKUL,A. \& KANKUAN, K. W. Anatomic position of the asterion and implication for neurosurgical procedure. Int. J. Morphol., 39(5):1429-1435, 2021.

SUMMARY: The asterion is the joining of the lambdoid, parietomastoid, and occipitomastoid sutures. It is classified into two types, type I shows small bones or woven bones, while in type II, woven bones are non-existent. In this study, forty cadavers were conducted and observed the asterion on both sides of skulls showing the approximate ratio of type II and type I was 3:2. The asterion was located by measuring the distances from the asterion to skull landmarks, including inion, the root of zygoma, and mastoid tip. The mean distance between asterion and inion was $62.9 \pm 6.0 \mathrm{~mm}$. The mean distance between asterion and the root of zygomatic arch was $58.3 \pm 6.1 \mathrm{~mm}$, whereas the mean distance between asterion and mastoid tip was $51.1 \pm 5.3 \mathrm{~mm}$. The most common location related to the asterion was the dural venous sinuses on $65 \%$ of tested sides, followed by infratentorial dura and supratentorial dura ( $25 \%$ and $10 \%$, respectively). However, the authors found no differences between sexes, sides, and types in any underlying structures.

KEY WORDS: Asterion; Skull; Dural venous sinus; Cadave; Thais.

\section{INTRODUCTION}

The knowledge of the superficial anatomy is crucial for the surgeon on the initial success of the neurosurgical approach. The asterion is the joining of the lambdoid, parietomastoid, and occipitomastoid sutures (Standring, 2016). It is a superficial anatomical landmark that has not been believed to be related to the underlying posterior fossa dura but indicated the location of the intracranial venous sinuses (Day \& Tschabitscher, 1998). Surgeons must consider the appropriate placement of burr holes for craniotomy at the retrosigmoid approach to avoid venous sinus injury and consequent bleeding (Raabe, 2019). As the location of the asterion varies, in the present study, the type of asterion, its relation to the underlying structure, and the distance from skull landmarks were observed from skulls of Thai male and female cadavers. Our findings could be helpful for surgeons in planning to approach posterolateral intracranial.

\section{MATERIAL AND METHOD}

After the institutional ethics committee approval (REC.64-031-19-2), forty adult human formalin-fixed cadaveric heads were collected from the Anatomy Program,
Division of Health and Applied Sciences, Faculty of Science. The scalp and soft tissue were removed to expose the lateral and posterior cranial areas, from the root of zygoma (ROZ) to inion, foramen magnum, and laterally to the mastoid tip on both sides. The heads presenting congenital anomalies of cranial or previous skull procedures were excluded. Cadaveric information, including age, sex, type of asterion, and the distance of surface anatomical landmarks to the position of asterion, was recorded and statistically analyzed. In addition, the relationship between asterion and the internal surface of the bone, especially the venous sinus in the posterior cranial fossa, was observed.

Type of asterion. The sutures, including lambdoid, occipitomastoid, parietomastoid, and squamosal in each specimen, were examined to identify the asterion type. The junction of all these sutures at the asterion area was classified into two types (Singh, 2012). Type I presented small bone or woven bone (Fig. 1A), and type II by absent woven bone (Fig. 1B).

Position of asterion. The distance between the critical surface anatomical landmarks, including the root of the zygomatic $\operatorname{arch}(\mathrm{ROZ})$, the tip of mastoid process (MT), and the inion 
(IN) to asterion were measured (Fig. 2) using stainless steel sliding calipers (Mitutoyo ${ }^{\circledR}$, Japan) with an accuracy of 0.01 $\mathrm{mm}$. All measurements were taken four times by two authors and then averaged to minimize bias errors. Then the authors drilled a small hole of $2 \mathrm{~mm}$ in diameter at asterion to evaluate the relationship between asterion and inner surface structures. The cranial vault above the hole was removed. In contrast, the underlying structure, the venous sinus in the posterior cranial fossa, was observed and classified into three groups, namely supratentorial dura, dural venous sinus, and infratentorial dura groups.

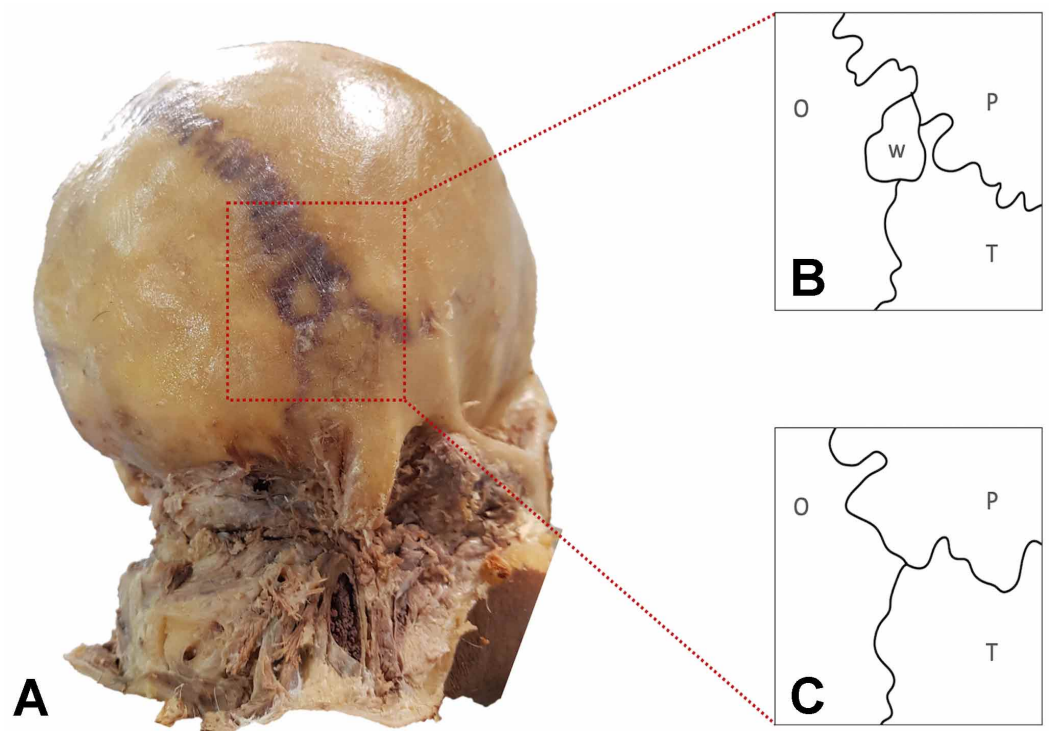

Fig. 1. Type of the asterion. (A) The right posterolateral view of cadaveric head after scalp and soft tissue removal. (B) Asterion type I. (C) Asterion type II. O: occipital bone, P: parietal bone, T: temporal bone, W: woven bone.

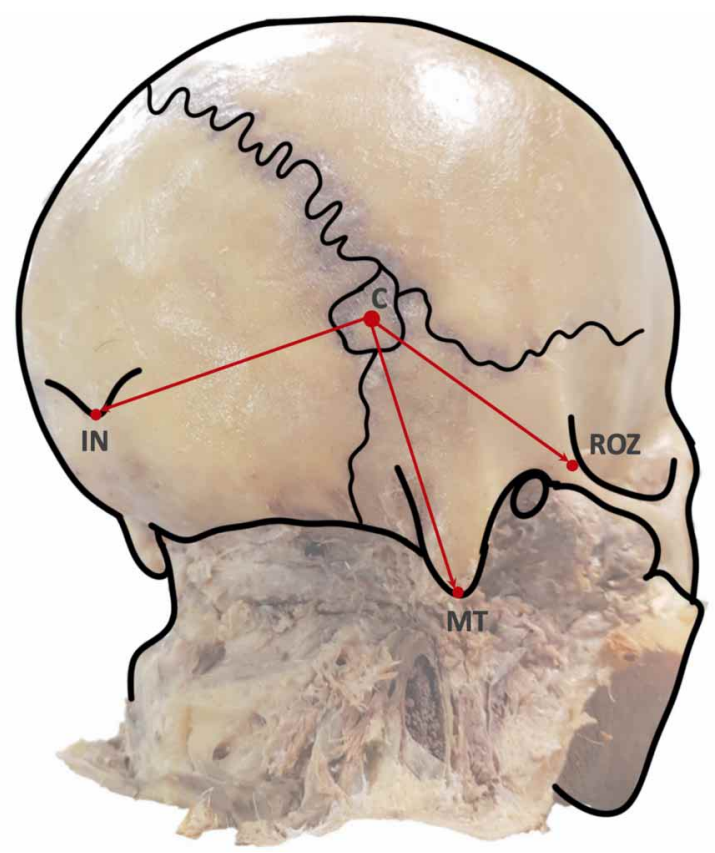

Fig. 2. The distance from the asterion to skull landmarks (on the right side). C: center of asterion, IN: inion, MT: mastoid tip, ROZ: root of zygoma.
The two authors (WK and WW) individually evaluated all aspects of the study. The authors decided upon the asterion type and its underlying structures in agreement. The distance between asterion to skull landmarks, as continuous data, was tested inter-rater reliability with Bland-Altman plots. Measurements exceeding the upper- or lower limit of the agreement were remeasured. This study used the mean distances for further statistical analysis.

\section{RESULTS}

The forty cadavers in the study consisted of seventeen females and twentythree males. The mean age of corpses was $78.2 \pm 13.0$ years, ranging from 41 to 102 years. Asterion was observed on both sides of skulls (80 sides) with a higher proportion of type II than type I asterion. The approximate ratio of asterion type II and type I was 3:2 (61.2\% and $38.8 \%$, respectively). By sex, the incidence of asterion type II was $73.5 \%$ in females and $52.2 \%$ in males, whereas type I was $26.5 \%$ in females and $47.8 \%$ in males (Table I). To compare the asterion type between sides, the prevalence of bilaterally asterion type II was more common than bilateral asterion type I ( $40.0 \%$ vs. $17.5 \%)$. However, there was no significant difference between sex and sides (Table I).

The location of the asterion was measured by the distances from the asterion to skull landmarks, including the root of zygoma, mastoid tip, and inion, which have been shown in Table II. The longest distance was found in the line between asterion and inion, $62.9 \pm 6.0 \mathrm{~mm}$. The mean 
Table I. Type of the asterion

\begin{tabular}{|c|c|c|c|c|c|c|c|c|c|c|c|c|}
\hline \multirow[t]{3}{*}{ Type } & \multicolumn{5}{|c|}{ By sex } & \multicolumn{5}{|c|}{ By side } & \multicolumn{2}{|c|}{ Total $(n=80)$} \\
\hline & \multicolumn{2}{|c|}{ Male $(n=46)$} & \multicolumn{2}{|c|}{ Female $(n=34)$} & \multirow[t]{2}{*}{$p$-value ${ }^{1}$} & \multicolumn{2}{|c|}{ Right $(\mathrm{n}=40)$} & \multicolumn{2}{|c|}{ Left $(n=40)$} & \multirow[t]{2}{*}{$p$-value ${ }^{1}$} & & \\
\hline & $\mathrm{n}$ & $\%$ & $\mathrm{n}$ & $\%$ & & $\mathrm{n}$ & $\%$ & $\mathrm{n}$ & $\%$ & & $\mathrm{n}$ & $\%$ \\
\hline I & 22 & 47.8 & 9 & 26.5 & 0.065 & 16 & 51.6 & 15 & 48.4 & 1.000 & 31 & 38.8 \\
\hline II & 24 & 52.2 & 25 & 73.5 & & 24 & 49.0 & 25 & 51.0 & & 49 & 61.2 \\
\hline
\end{tabular}

${ }^{1}$ Exact probability test

distance between asterion and root of the zygomatic arch was $58.3 \pm 6.1 \mathrm{~mm}$. The shortest distance was found in the line between asterion and mastoid tip, $51.1 \pm 5.3 \mathrm{~mm}$. In addition, the authors collected and analyzed the database on sexes, sides, and types of asterion as followed.

By the sex, the locations of the asterion from each bony landmark were similar in female and male. The mean distance between asterion and inion was $62.2 \pm 5.3 \mathrm{~mm}$ in female and $63.5 \pm 6.5 \mathrm{~mm}$ in male, the mean distance between asterion and root of the zygomatic arch was $58.0 \pm$ $4.9 \mathrm{~mm}$ in female and $58.6 \pm 6.9 \mathrm{~mm}$ in male, and the mean distance between asterion and mastoid tip was $49.8 \pm 4.4$ $\mathrm{mm}$ in female and $52.1 \pm 5.8 \mathrm{~mm}$ in male (Table II).

By the side, the distances from the asterion to inion, the root of the zygomatic arch, and the mastoid tip were similar. The mean distance between asterion and inion was $63.9 \pm$ $6.4 \mathrm{~mm}$ on the right side and $62.0 \pm 5.6 \mathrm{~mm}$ on the left side. In contrast, the mean distance between asterion and root of the zygomatic arch was $57.8 \pm 6.6 \mathrm{~mm}$ on the right side and $58.9 \pm 5.7 \mathrm{~mm}$ on the left side, and the mean distance between asterion and mastoid tip was $51.2 \pm 5.6 \mathrm{~mm}$ on the right side and $51.0 \pm 5.1 \mathrm{~mm}$ in the left side (Table II).

The mean distances between asterion and inion were $64.5 \pm 7.9 \mathrm{~mm}$ and $61.9 \pm 4.3 \mathrm{~mm}$ (type I and II, respectively) by type of asterion. The mean distances between asterion and root of the zygomatic arch were $56.6 \pm 7.7 \mathrm{~mm}$ in the type I asterion and $59.5 \pm 4.7 \mathrm{~mm}$ in the type II asterion. The latter distances were $50.4 \pm 5.0 \mathrm{~mm}$ and $51.6 \pm 5.5 \mathrm{~mm}$ in type I and II, respectively (Table II).

After the asterion types and locations were identified, the authors found that the most common location related to the asterion was the dural venous sinus on $65 \%$ of tested sides, followed by the infratentorial dura and supratentorial dura ( 25 $\%$ and $10 \%$, respectively). The type I asterion was rather associated with the venous sinus than infratentorial and supratentorial dura $(71 \%, 12.9 \%$, and $16.1 \%$, respectively). Similarly, the type II asterion was located at the venous sinus in $61.2 \%$, followed by infratentorial dura and supratentorial dura (32.7\% and $6.1 \%$, respectively) (Table III). Significantly, the location of asterion overlaid the dural venous sinus; it was typically in the transverse-sigmoid sinus junction (51.2\%), only fifteen asterions $(18.8 \%$ ) were located at posterior fossa dura that just inferiorly to the transverse-sigmoid sinus junction, and four asterion $(5 \%)$ were superior to the transverse-sigmoid sinus junction. At the transverse sinus area, eleven asterions $(13.8 \%)$ were located, and five asterions (6.2 $\%$ ) were inferior to the transverse sinus, while the lastly four asterions (5\%) were superior to the transverse sinus (Fig. 3). However, the authors found no differences between sexes, sides, and types in any underlying structures.

Table II. Distance from asterion to anatomical landmarks ( $\mathrm{mm})$.

\begin{tabular}{|c|c|c|c|c|c|c|c|c|c|c|}
\hline \multirow[t]{3}{*}{ Distance } & \multicolumn{2}{|c|}{ By sex } & \multirow{3}{*}{ p-value ${ }^{1}$} & \multicolumn{2}{|c|}{ By side } & \multirow{3}{*}{$\mathrm{p}$-value ${ }^{1}$} & \multicolumn{2}{|c|}{ By type } & \multirow{3}{*}{ p-value ${ }^{1}$} & \multirow[t]{2}{*}{ Total } \\
\hline & $\begin{array}{l}\text { Male } \\
(n=46)\end{array}$ & $\begin{array}{l}\text { Female } \\
(\mathrm{n}=34)\end{array}$ & & $\begin{array}{l}\text { Right } \\
(\mathrm{n}=40)\end{array}$ & $\begin{array}{l}\text { Left } \\
(n=40)\end{array}$ & & $\begin{array}{l}\mathrm{I} \\
(\mathrm{n}=31)\end{array}$ & $\begin{array}{l}\text { II } \\
(\mathrm{n}=49)\end{array}$ & & \\
\hline & Mean \pm SD & Mean \pm SD & & Mean \pm SD & Mean \pm SD & & Mean \pm SD & Mean \pm SD & & Mean \pm SD \\
\hline AS - ROZ & $58.59 \pm 6.92$ & $58.01 \pm 4.93$ & 0.289 & $57.82 \pm 6.60$ & $58.87 \pm 5.66$ & 0.389 & $56.58 \pm 7.66$ & $59.46 \pm 4.67$ & 0.1593 & $58.34 \pm 6.13$ \\
\hline AS - MT & $52.11 \pm 5.79$ & $49.83 \pm 4.38$ & 0.070 & $51.24 \pm 5.58$ & $51.04 \pm 5.13$ & 0.889 & $50.36 \pm 5.00$ & $51.64 \pm 5.52$ & 0.435 & $51.14 \pm 5.33$ \\
\hline AS - IN & $63.50 \pm 6.54$ & $62.18 \pm 5.29$ & 0.316 & $63.90 \pm 6.42$ & $61.97 \pm 5.55$ & 0.084 & $64.51 \pm 7.86$ & $61.94 \pm 4.34$ & 0.577 & $62.94 \pm 6.04$ \\
\hline
\end{tabular}

${ }^{1}$ Two-sample Wilcoxon rank-sum (Mann-Whitney) test. AS: asterion, IN: inion, MT: mastoid tip, ROZ: root of zygoma.

Table III. Association between type of Asterion and its beneath structures.

\begin{tabular}{|c|c|c|c|c|c|c|c|}
\hline \multirow[t]{3}{*}{ Type } & \multicolumn{6}{|c|}{ Structures beneath the Asterion } & \multirow[t]{3}{*}{ p-value ${ }^{1}$} \\
\hline & \multicolumn{2}{|c|}{$\begin{array}{c}\text { Infratentorial } \\
\text { dura }\end{array}$} & \multicolumn{2}{|c|}{$\begin{array}{l}\text { Venous } \\
\text { sinus }\end{array}$} & \multicolumn{2}{|c|}{$\begin{array}{c}\text { Supratentorial } \\
\text { dura }\end{array}$} & \\
\hline & $\mathrm{n}$ & $(\%)$ & $\mathrm{n}$ & $(\%)$ & $\mathrm{n}$ & $(\%)$ & \\
\hline I $(n=31)$ & 4 & $(12.9)$ & 22 & $(71.0)$ & 5 & $(16.1)$ & 0.077 \\
\hline II $(n=49)$ & 16 & $(32.7)$ & 30 & $(61.2)$ & 3 & $(6.1)$ & \\
\hline Total & 20 & $(25)$ & 52 & $(65.0)$ & 8 & (10) & \\
\hline
\end{tabular}

${ }^{1}$ Exact probability test. 


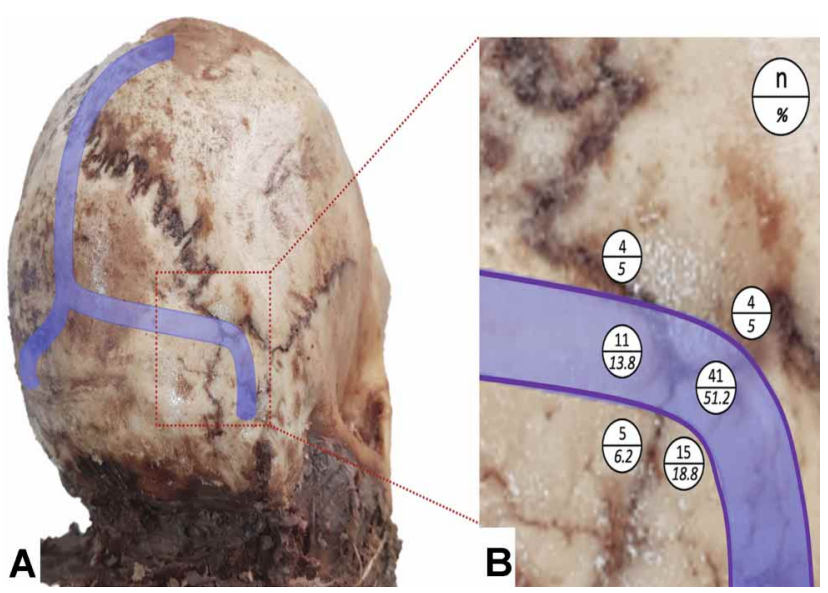

Fig. 3. Position of the asterion in relation to beneath dura and the sinus (purple color). (A) The right posterolateral view of cadaveric head showing the underneath the right transverse and sigmoid sinus. (B) The magnification view, the circle showing the number (n) and percentage $(\%)$ of the location of the center of asterion over each area.

\section{DISCUSSION}

Table IV. Previous studies of type and location of asterion.

\begin{tabular}{|c|c|c|c|c|c|c|c|c|}
\hline \multirow[t]{2}{*}{ Country } & \multirow[t]{2}{*}{ Authors (year) } & \multirow{2}{*}{$\begin{array}{l}\text { Number } \\
\text { of sides }\end{array}$} & & \multicolumn{2}{|c|}{ Type of asterion (\%) } & \multicolumn{3}{|c|}{ Distance from asterion to landmarks (mm) } \\
\hline & & & & I & II & AS - ROZ & AS - MT & AS - IN \\
\hline Turkey & Ucerler et al., 2006. & 100 & & NA & NA & $54.6 \pm 5.5$ & $49.1 \pm 5.4$ & NA \\
\hline \multirow{2}{*}{ Kenya } & Mwachaka et al., 2010. & 63 & Male & NA & NA & $59.06 \pm 2.72$ & $48.36 \pm 2.72 *$ & NA \\
\hline & & 38 & Female & NA & NA & $58.75 \pm 2.02$ & $46.62 \pm 3.37 *$ & NA \\
\hline \multirow[t]{10}{*}{ India } & Singh, 2012. & 56 & Male & 17.9 & 82.1 & NA & NA & NA \\
\hline & & 54 & Female & 14.8 & 85.2 & NA & NA & NA \\
\hline & Havaldar et al., 2015. & 296 & Male & 18.3 & 81.7 & NA & NA & NA \\
\hline & & 204 & Female & 20.6 & 79.4 & NA & NA & NA \\
\hline & Deepak et al., 2015. & 54 & Male & 25.9 & 74.1 & NA & NA & NA \\
\hline & & & Right & & & NA & $50.9 \pm 4.9$ & $55.8 \pm 9.5$ \\
\hline & & & Left & & & NA & $48.5 \pm 8.5$ & $56.9 \pm 8.5$ \\
\hline & & 46 & Female & 28.2 & 71.7 & & & \\
\hline & & & Right & & & NA & $45.5 \pm 6.7$ & $58.9 \pm 7.6$ \\
\hline & & & Left & & & NA & $45.5 \pm 5.5$ & $57.0 \pm 7.9$ \\
\hline \multirow[t]{6}{*}{ Iran } & Gharehdaghi et al., 2019. & 146 & Male & 13.7 & 86.3 & & & \\
\hline & & & Right & & & NA & $48.43 \pm 2.04$ & $72.87 \pm 1.64^{*}$ \\
\hline & & & Left & & & NA & $47.60 \pm 2.02 *$ & $72.49 \pm 1.45$ \\
\hline & & 64 & Female & 14.7 & 85.2 & & & \\
\hline & & & Right & & & NA & $43.84 \pm 1.62$ & $64.46 \pm 3.8^{*}$ \\
\hline & & & Left & & & NA & $44.15 \pm 2.35^{*}$ & $64.96 \pm 4.01$ \\
\hline \multirow[t]{6}{*}{ Thailand } & Present study. & 46 & Male & 47.8 & 52.2 & $58.59 \pm 6.92$ & $52.11 \pm 5.79$ & $63.50 \pm 6.54$ \\
\hline & & & Right & & & $58.41 \pm 7.46$ & $51.88 \pm 6.26$ & $64.26 \pm 6.80$ \\
\hline & & & Left & & & $58.77 \pm 6.51$ & $52.35 \pm 5.41$ & $62.74 \pm 6.32$ \\
\hline & & 34 & Female & 26.5 & 73.5 & $58.01 \pm 4.93$ & $49.83 \pm 4.38$ & $62.18 \pm 5.29$ \\
\hline & & & Right & & & $57.01 \pm 5.33$ & $50.38 \pm 4.57$ & $63.42 \pm 6.03$ \\
\hline & & & Left & & & $59.02 \pm 4.43$ & $49.28 \pm 4.25$ & $60.93 \pm 4.26$ \\
\hline
\end{tabular}

AS: asterion, IN: inion, MT: mastoid tip, ROZ: root of zygoma, NA: not available, *statistical significant.
In brain tumor surgery, the asterion is used as a landmark in the posterolateral region, such as the retrosigmoid approach for tumor resection in the cerebellopontine angle and the suprapetrosal approach for petrous lesions, so the right point at the beginning of craniotomy is desirable to approach into skull cavity (Lang Jr. \& Samii, 1991; Ribas et al., 2005; Ribas \& Rodrigues, 2007). Asterion is classified as type I and II, where type II commonly occurs. It can be found some small ossicles named Wormian bones (Berry \& Berry, 1967; Singh) that derived from the abnormal ossification centers fused into the typical structure during the skull development (Bellary et al., 2013). The appearance of Wormian bones may be related to genetic factors, artificial cranial deformation, an adaptation of skull growth, and metabolic disorders (Manjula \& Santosh, 2012; Cirpan et al., 2015; Hardy \& Fernandez-Patron, 2020).

In the previous report of Thailand, asterion was easily detected in the dry skull, but it was identified with 60-80\% correctness in fresh cadaver or formalin-fixed heads (Avci et al., 2003; Duangthongpon et al., 2016). However, in this study, the authors ultimately identified both types of asterion in all formalin-fixed cadavers and provided valuable information on asterion types and landmarks in Thai 
cadavers. The asterion type found in Thai female cadaveric skulls was similar to males, where the occurrence of asterion type II is followed by asterion type I. As well as in Thais, the asterion type II was always the most found in several ethnicities, including Turks (Ucerler \& Govsa, 2006), Kenyans (Mwachaka et al., 2010), Indians (Singh; Pavan et al., 2015; Deepak \& Dakshayani, 2015), and Iranians (Gharehdaghi et al., 2020) (Table IV). However, the occurrence of asterion type I in the Thai population was significantly higher than those studied in other races. For the asterion type I or asterion presented with sutural bone, the authors observed a connective tissue perched along the suture edge; this tissue could be the cause for unclear asterion identification and asterion type classification in the cadaveric skulls.

The measurements of the asterion location with other pronounced anatomical landmarks related provide information for the clinical, surgical procedures. The authors collected the database in which the mean distance between the asterion and the inion, zygoma root, and mastoid tip were comparable with the earlier studies' results (Table IV).

On the point of the asterion to the inion distance, in Indians, Deepak \& Dakshayani, reported $55.8 \pm 9.5 \mathrm{~mm}$ on the right, $56.9 \pm 8.5 \mathrm{~mm}$ on the left on male craniums, 58.9 $\pm 7.6 \mathrm{~mm}$ on the right, $57.0 \pm 7.9 \mathrm{~mm}$ on the left on female craniums. In Iranian, Gharehdaghi et al. study found significant differences in distance between the left and right sides in both males and females. They recorded 72.9 \pm 1.6 $\mathrm{mm}$ on the right, $72.5 \pm 1.5 \mathrm{~mm}$ on the left on male skulls, $64.5 \pm 3.8 \mathrm{~mm}$ on the right, $65.0 \pm 4 \mathrm{~mm}$ on the left on female skulls. We measured $64.3 \pm 6.8 \mathrm{~mm}$ on the right, $62.7 \pm 6.3 \mathrm{~mm}$ on the left on male skulls, $63.4 \pm 6.0 \mathrm{~mm}$ on the right, $60.9 \pm 4.3 \mathrm{~mm}$ on the left on female skulls in our study (Table IV).

The distance of asterion to the root of zygoma, most of the results were consistent in each race. In Turkish skulls, Ucerler \& Govsa measured 54.6 $\pm 5.5 \mathrm{~mm}$ totally. Mwachaka et al. reported $59.1 \pm 2.7 \mathrm{~mm}$ in Kenyan males and $58.8 \pm$ $2.0 \mathrm{~mm}$ in Kenyan females. In this study, we reported 58.4 $\pm 7.5 \mathrm{~mm}$ on the right and $58.8 \pm 6.5 \mathrm{~mm}$ on the left of male skulls, $57.0 \pm 5.3 \mathrm{~mm}$ on the right and $59.0 \pm 4.4 \mathrm{~mm}$ on left female skulls. There was no significant difference in distance between sides and sexes in our study (Table IV).

The distance between asterion and mastoid tip process, Ucerler \& Govsa reported measured 49.1 $\pm 5.4 \mathrm{~mm}$ totally in Turkish skulls. In Indians, Deepak \& Dakshayani reported $50.9 \pm 4.9 \mathrm{~mm}$ on the right, $48.5 \pm 8.5 \mathrm{~mm}$ on the left on male skulls, $45.5 \pm 6.7 \mathrm{~mm}$ on the right, $45.5 \pm 5.5$ $\mathrm{mm}$ on the left on female skulls. However, there was a sign of this distance between Kenyans and Iranians. Mwachaka et al., who found differences between distances in males and females, recorded $48.4 \pm 2.7 \mathrm{~mm}$ in Kenyan males and $46.6 \pm 3.8 \mathrm{~mm}$ in Kenyan females. In contrast, Gharehdaghi et al. reported significant differences in distance between the left and right sides in both males and females. They recorded $48.4 \pm 2.0 \mathrm{~mm}$ on the right, $47.6 \pm 2.0 \mathrm{~mm}$ on the left on male skulls, $43.8 \pm 1.6 \mathrm{~mm}$ on the right, $44.2 \pm 2.4 \mathrm{~mm}$ on the left on female skulls. In this study, we found no difference in distance between sides and sexes, $51.9 \pm 6.3 \mathrm{~mm}$ on the right and $52.4 \pm 5.4 \mathrm{~mm}$ on left of male skulls, $50.4 \pm$ $4.6 \mathrm{~mm}$ on the right and $49.3 \pm 4.3 \mathrm{~mm}$ on left female skulls (Table IV).

Nowadays, a microsurgical innovation technique as the key-hole craniotomy can replace large craniotomies to provide shorter surgery time and avoid severe complications in neurosurgery; the relationship between surface anatomy and underneath structure must be crucially concerned. The venous sinus was the most common location related to the asterion in several studies (Table V). Also, in Thailand, a study led by Sripairojkul \& Adultrakoon (2000) observed the asterion in $66.3 \%$ cases above the venous sinuses, $16.3 \%$ infratentorial, and $17.4 \%$ supratentorial. In contrast, in the study by Duanthongpon et al. (2016) in $90.9 \%$ cases the asterion was above venous sinuses, in $3 \%$ located at the infratentorial, and in $6.1 \%$ at supratentorial position (Table V).

Table V. Previous studies of the structure beneath the asterion.

\begin{tabular}{llcccc}
\hline Country & Authors (year) & \multirow{2}{*}{$\begin{array}{c}\text { Number } \\
\text { of sides }\end{array}$} & & \multicolumn{2}{l}{ Structures beneath the asterion (\%) } \\
\cline { 4 - 5 } & & & Infratentorial dura & Venous sinus & Supratentorial dura \\
\hline Turkey & Ucerler et al., 2006. & 100 & 11.0 & 87.0 & 2.0 \\
Kenya & Mwachaka et al., 2010. & 180 & 0.6 & 80.0 & 19.4 \\
China & Sheng et al, 2012 & 200 & 0.5 & 78.5 & 21.0 \\
India & Deepak et al., 2015. & 100 & 32.0 & 62.0 & 6.0 \\
Iran & Gharehdaghi et al., 2019. & 210 & 30.5 & 58.1 & 11.4 \\
Thailand & Sripairojkul et al., 2000. & 86 & 16.3 & 66.3 & 17.4 \\
& Duangthongpon et al., 2016. & 33 & 3.0 & 90.9 & 6.1 \\
& Present study. & 80 & 25.0 & 65.0 & 10.0 \\
\hline
\end{tabular}


In the previous studies, Day \& Tschabitscher concluded that the asterion is an unreliable landmark for posterolateral craniotomy. However, a more accurate performance of craniotomy, which aims to identify posterior fossa dura and transverse-sigmoid junction, needs other assisting methods, such as the neuronavigational system. However, the system has limited availability or accessibility, especially in countries with low resources (Gnanakumar et al., 2020). Hall \& Gan (2019) compared the qualitative and quantitative differences between ten methods to approach the posterior fossa dura at the transverse-sigmoid sinus junction, also called key point. They showed asterion positions away from the key point with an average of $13.9 \pm 5.2 \mathrm{~mm}$ and proposed a method with the highest accuracy to intraoperative application. In a retrosigmoid approach described by Li et al. (2014) as novel coordinate system, the placement of the initial burr hole was $6.3 \pm 2.9 \mathrm{~mm}$ away from the key point. It is known that each patient's key point position is located differently (Hall \& Gan). Therefore, planning the surgery with the information of the patient is probably a suitable method. Xia et al. (2012) studied eighteen patients who underwent retrosigmoid craniotomy by surgery planning to place the burr hole at the key point with a preoperative $3 \mathrm{D}$ computed tomography comparing the position of asterion and digastric groove. There the burr hole was set at the corrected key point position and led to no venous sinus injury.

Therefore, our findings may help to recognize the variation of asterion type and its location in terms of distance from other skull landmarks and beneath structures. However, this study was limited by the small numbers of cadaveric heads in southern Thailand. Further work, as multi-institutes in different regions, is required to establish the exact information for Thai people.

ACKNOWLEDGMENTS. The authors would like to acknowledge the Anatomy Program, Division of Health and Applied Sciences, Faculty of Science, Prince of Songkla University for their support of this research, and thank Mrs. Anna Chatthong for her assistance with the English language. The authors are grateful to the supporting team of the anatomy program for their help and to those who donated their bodies for anatomical study.

WIRAKIAT, W.; KAEWBORISUTSAKUL,A. \& KANKUAN, K. W. Posición anatómica del asterion y sus implicancias en el procedimiento neuroquirúrgico. Int. J. Morphol., 39(5):1429-1435, 2021.

RESUMEN: El asterion es la unión de las suturas lambdoidea, parietomastoidea y occipitomastoidea. Clasificado en dos tipos, el tipo I muestra huesos pequeños o hueso laminar, mien- tras que en el tipo II, el hueso laminar es inexistente. En este trabajo se estudiaron 40 cadáveres y se observó el asterion en ambos lados de los cráneos correspondientes, mostrando una proporción aproximada de tipo II y tipo I de 3:2. El asterion se localizó midiendo las distancias asociadas a puntos de referencia del cráneo: el inion, la raíz del arco cigomático y el ápice del proceso mastoides. La distancia media entre el asterion y el inion fue de 62,9 $\pm 6,0$ $\mathrm{mm}$. La distancia media entre el asterion y la raíz del arco cigomático fue de 58,3 $\pm 6,1 \mathrm{~mm}$, mientras que la distancia media entre el asterion y el ápice del proceso mastoides fue de 51,1 $\pm 5,3$ $\mathrm{mm}$. La localización más común relacionada con el asterion fueron los senos venosos durales en el $65 \%$ de los lados evaluados, seguido de la duramadre infratentorial y la dura supratentorial (25 $\%$ y $10 \%$, respectivamente). Sin embargo, los autores no encontraron diferencias entre sexo, lados y tipo en ninguna estructura subyacente.

PALABRAS CLAVE: Asterion; Cráneo; Seno venoso dural; Cadáver; Tailandés.

\section{REFERENCES}

Avci, E.; Kocaogullar, Y.; Fossett, D. \& Caputy, A. Lateral posterior fossa venous sinus relationships to surface landmarks. Surg. Neurol., 59(5):392-7, 2003.

Bellary, S. S.; Steinberg, A.; Mirzayan, N.; Shirak, M.; Tubbs, R. S.; Cohen-Gadol, A. A. \& Loukas, M. Wormian bones: a review. Clin. Anat., 26(8):922-7, 2013.

Berry, A. C. \& Berry, R. J. Epigenetic variation in the human cranium. J. Anat., 101(Pt. 2):361-79, 1967.

Cirpan, S.; Aksu, F. \& Mas, N. The incidence and topographic distribution of sutures including wormian bones in human skulls. J. Craniofac. Surg., 26(5):1687-90, 2015.

Day, J. D. \& Tschabitscher, M. Anatomic position of the asterion. Neurosurgery, 42(1):198-9, 1998.

Deepak, S. \& Dakshayani, K. R. Morphometric features of asterion in adult human skulls. Int. J. Res. Med. Sci., 3(6):1325-8, 2015.

Duangthongpon, P.; Thanapaisal, C.; Kitkhuandee, A.; Chaiciwamongkol, K. \& Morthong, V. The relationships between asterion, the transverse-sigmoid junction, the superior nuchal line and the transverse sinus in Thai cadavers: Surgical relevance. $J$. Med. Assoc. Thai., 99 Suppl. 5:S127-31, 2016.

Gharehdaghi, J.; Jafari-Marandi, H.; Faress, F.; Zeinali, M. \& Safari, H. Morphology of asterion and its proximity to deep vein sinuses in Iranian adult skull. Br. J. Neurosurg., 34(1):55-8, 2020.

Gnanakumar, S.; Abou El Ela Bourquin, B.; Robertson, F. C.; Solla, D. J. F.; Karekezi, C.; Vaughan, K.; Garcia, R. M.; Hassani, F. D.; Alamri, A.; Höhne, J.; et al. The World Federation of Neurosurgical Societies Young Neurosurgeons Survey (Part I): demographics, resources, and education. World Neurosurg. X, $8: 100083,2020$.

Hall, S. \& Gan, Y. C. P.s Anatomical localization of the transversesigmoid sinus junction: Comparison of existing techniques. Surg. Neurol. Int., 10:186, 2019.

Hardy, E. \& Fernandez-Patron, C. Destroy to rebuild: The connection between bone tissue remodeling and matrix metalloproteinases. Front. Physiol., 11:47, 2020.

Lang Jr., J. \& Samii, A. Retrosigmoidal approach to the posterior cranial fossa. An anatomical study. Acta Neurochir. (Wien), 111(34):147-53, 1991. 
Li, R. C.; Li, K.; Qi, L.; Xu, G. F.; Xie, W. F.; Wang, M. D. \& Bao, G. A novel reference coordinate system to locate the inferomedial point of the transverse-sigmoid sinus junction. Acta Neurochir. (Wien), 156(11):2209-13, 2014.

Manjula, P. \& Santosh, S. Sexual dimorphism among the Wormian bone in adult human skulls. J. Indian Acad. Forensic Med., 34(2):124-7, 2012.

Mwachaka, P. M.; Hassanali, J. \& Odula, P. O. Anatomic position of the asterion in Kenyans for posterolateral surgical approaches to cranial cavity. Clin. Anat., 23(1):30-3, 2010.

Pavan, P. H.; Shruthi, B. N.; Hussain Saheb, S. \& Henjarappa, K. S. Morphological study on types of asterion. Int. J. Integr. Med. Sci., 2(10):167-9, 2015.

Raabe, A. The Craniotomy Atlas. New York, Thieme, 2019.

Ribas, G. C. \& Rodrigues, A. J. J. The suprapetrosal craniotomy. J. Neurosurg., 106(3):449-54, 2007.

Ribas, G. C.; Rhoton Jr., A. L.; Cruz, O. R. \& Peace, D. Suboccipital burr holes and craniectomies. Neurosurg. Focus, 19(2):E1, 2005.

Singh, R. Incidence of sutural bones at asterion in adults Indians skulls. Int. J. Morphol., 30(3):1182-6, 2012.

Sripairojkul, B. \& Adultrakoon, A. Anatomical position of the asterion and its underlying structure. J. Med. Assoc. Thai., 83(9):1112-5, 2000 .

Standring, S. Gray's Anatomy: The Anatomical Basis of Clinical Practice. 41st ed. New York, Elsevier, 2016.

Ucerler, H. \& Govsa, F. Asterion as a surgical landmark for lateral cranial base approaches. J. Craniomaxillofac. Surg., 34(7):415$20,2006$.

Xia, L.; Zhang, M.; Qu, Y.; Ren, M.; Wang, H.; Zhang, H.; Yu, C.; Zhu, M. \& Li, J. Localization of transverse-sigmoid sinus junction using preoperative $3 \mathrm{D}$ computed tomography: application in retrosigmoid craniotomy. Neurosurg. Rev., 35(4):593-8, 2012.
Corresponding author:

Wilairat Kankuan Kaewborisutsakul, Ph.D

Anatomy Program

Division of Health and Applied Sciences

Faculty of Science

Prince of Songkla University

Hat Yai, Songkhla 90110

THAILAND

E-mail: wilairat.k@psu.ac.th

Received : 22-06-2021

Accepted : 28-07-2021 